\title{
Application of hyperthermia induced by superparamagnetic iron oxide nanoparticles in glioma treatment
}

This article was published in the following Dove Press journal:

International Journal of Nanomedicine

24 March 201I

Number of times this article has been viewed

\author{
André C Silva' \\ Tiago R Oliveira ${ }^{1,2}$ \\ Javier B Mamani' \\ Suzana MF Malheiros 3 3,4 \\ Luciana Malavolta' \\ Lorena F Pavon' \\ Tatiana T Sibov' \\ Edson Amaro Jr ${ }^{1,5}$ \\ Alberto Tannús ${ }^{6}$ \\ Edson LG Vidoto ${ }^{6}$ \\ Mateus J Martins ${ }^{6}$ \\ Ricardo S Santos ${ }^{6}$ \\ Lionel F Gamarra' \\ 'Instituto Israelita de Ensino e \\ Pesquisa Albert Einstein, IIEPAE, \\ São Paulo, Brazil; ${ }^{2}$ Instituto de Física, \\ Universidade de São Paulo, São Paulo, \\ Brazil; ${ }^{3}$ Departament of Neurology \\ and Neurosurgery, Universidade \\ Federal de São Paulo, São Paulo, \\ Brazil; ${ }^{4}$ Neuro-Oncology Program \\ of Hospital Israelita Albert Einstein, \\ São Paulo, Brazil; ${ }^{5}$ nstituto de \\ Radiologia, Faculdade de Medicina; \\ ${ }^{6} \mathrm{CIERMag-Instituto} \mathrm{de} \mathrm{Física} \mathrm{de} \mathrm{São}$ \\ Carlos, Universidade de São Paulo, \\ São Paulo, Brazil
}

Correspondence: LF Gamarra Instituto Israelita de Ensino e Pesquisa Albert Einstein (IIEPAE) - Sociedade Beneficente Israelita Brasileira Hospital Albert Einstein (SBIBHAE). Av. Albert Einstein, 627/70I-Piso Chinuch ( $2^{\circ}$. Subsolo), Morumbi - São Paulo/SP Brazil - CEP: 0565I-90I

Tel +55 II 3747 I 366

Fax +55 II 38I 34334

Email Igamarra@einstein.br

\begin{abstract}
Gliomas are a group of heterogeneous primary central nervous system (CNS) tumors arising from the glial cells. Malignant gliomas account for a majority of malignant primary CNS tumors and are associated with high morbidity and mortality. Glioblastoma is the most frequent and malignant glioma, and despite the recent advances in diagnosis and new treatment options, its prognosis remains dismal. New opportunities for the development of effective therapies for malignant gliomas are urgently needed. Magnetic hyperthermia (MHT), which consists of heat generation in the region of the tumor through the application of magnetic nanoparticles subjected to an alternating magnetic field (AMF), has shown positive results in both preclinical and clinical assays. The aim of this review is to assess the relevance of hyperthermia induced by magnetic nanoparticles in the treatment of gliomas and to note the possible variations of the technique and its implication on the effectiveness of the treatment. We performed an electronic search in the literature from January 1990 to October 2010, in various databases, and after application of the inclusion criteria we obtained a total of 15 articles. In vitro studies and studies using animal models showed that MHT was effective in the promotion of tumor cell death and reduction of tumor mass or increase in survival. Two clinical studies showed that MHT could be applied safely and with few side effects. Some studies suggested that mechanisms of cell death, such as apoptosis, necrosis, and antitumor immune response were triggered by MHT. Based on these data, we could conclude that MHT proved to be efficient in most of the experiments, and that the improvement of the nanocomposites as well as the AMF equipment might contribute toward establishing MHT as a promising tool in the treatment of malignant gliomas.
\end{abstract}

Keywords: brain tumor, magnetic hyperthermia, magnetic nanoparticle

\section{Introduction}

In recent decades, a major challenge for oncologists and neuroscientists has been the understanding of biological mechanisms underlying the formation of tumors in the central nervous system (CNS), as well as the development of therapies that can stabilize, reduce or even eliminate these tumors. Primary malignant CNS tumors represent $1.49 \%$ of all cancers; however, although relatively rare, they are associated with high morbidity and mortality. ${ }^{1}$ Most of these tumors that originate from glial cells are usually referred to as gliomas. ${ }^{2}$

Gliomas are a group of heterogeneous CNS neoplasms that can be classified according to the glial cell of origin (ie, astrocytes, oligodendrocytes, ependymal cells, or choroid plexus cells). ${ }^{3}$ Gliomas are neuroepithelial tumors, which account for $33 \%$ of primary tumors and $79 \%$ of malignant CNS tumors. Astrocytomas represent $75 \%$ of all gliomas, and glioblastomas form $51.7 \%$ of cases. ${ }^{1}$ Glioblastoma is the most 
frequent and malignant astrocytoma, and despite advances in diagnosis and treatment of these tumors, their prognosis remains dismal. ${ }^{4,5}$ The development of new effective therapies is urgently needed. Hyperthermia induced by magnetic nanoparticles in tumor tissues is a potential therapeutic tool and has been evaluated by various ex-vivo experiments (fragments of tumor tissue removed by surgery) in animal models, with promising results, prompting Phase I studies in humans. ${ }^{6,7}$

Hyperthermia is a therapeutic procedure that promotes the increase of temperature in body tissues in order to change the functionality of the cellular structures. Its activity is based on the fact that a temperature increase of between $41^{\circ} \mathrm{C}$ and $42^{\circ} \mathrm{C}$ can induce tumor cell death, as the tumor cells are less resistant to sudden increases in temperature than the normal surrounding cells. ${ }^{8}$ The rise in temperature changes the functioning of many enzymatic and structural proteins in the cells, in turn altering cell growth and differentiation, which can induce apoptosis. ${ }^{9,10}$ Changes triggered by hyperthermia in the cell membrane lead to a reduction in transmembrane transport and destabilize its potential. ${ }^{11,12}$ It is also known that the rise in temperature can affect the synthesis of nucleic acids and inhibition of repair enzymes, and promote changes in the conformation of DNA. ${ }^{13}$ The temperature increase required by hyperthermia can be achieved via different heat sources, such as electromagnetic radiation waves (hyperthermia by radiofrequency or microwave), ${ }^{14,15}$ ultrasound waves, ${ }^{16-18}$ or electrically induced hyperthermia. ${ }^{19}$ These techniques have shown good results, however, the major problem with present conventional methods is reaching a heat homogenous distribution and therapeutic temperatures in the deep region of the tumor to be treated. In this sense, treatment failure results from an insufficient temperature rise in some parts of the tumor, allowing the tumor to recur. What also must be avoided is the excessive increase in temperature which would cause peritumoral tissue damage. The magnetic hyperthermia (MHT) technique has partly solved these problems.

Studies on the application of magnetic materials to promote hyperthermia began with Gilchrist et $\mathrm{al}^{20}$ in the late 1950s. After this work, many empirical studies have been carried out to evaluate the therapeutic expression in different tumor types. However, the results of these preliminary studies had their widespread use in academic circles only in the early 1990s, and today there are a small number of clinical studies in this area. ${ }^{21-24}$ Thus, more detailed studies on the physical limitations, degree of toxicity, and efficiency that would allow a better applicability of the method to humans are needed.
The principle of MHT comprises the administration of a magnetic fluid within the tumor for subsequent application of an alternating magnetic field (AMF), which will promote warming of the region. ${ }^{20}$ At present, MHT is presented as a noninvasive promising technique, efficient in implementing hyperthermia in deep and inaccessible tissues. The advantage of MHT is related to its specificity to tumorigenic tissues, ensuring less damage to healthy tissues due to the uniform distribution of temperature and the high rate of heat transfer.

The efficiency of the MHT technique is extremely dependent on the different properties of the particles, such as size, magnetization, and the value of the Curie temperature. The Curie temperature is the maximum temperature reached by a magnetic particle. Knowledge about the Curie temperature of a magnetic particle allows an efficient temperature control to avoid overheating the tissue. ${ }^{25}$ Of great importance are also the different parameters of the magnetic field used, such as intensity and frequency that will achieve the desired temperature. ${ }^{26}$ The main aim in this area is to improve the parameters above in order to obtain the best treatment efficacy. At present, some preliminary studies $^{23,27}$ that practice the clinical use of MHT to treat gliomas suggest that the superparamagnetic nanoparticles of iron oxide (SPION) have appropriate intratumoral distribution and are able to promote controlled heating of the region to hyperthermic temperatures without causing major side effects. In this sense, the objective of this review is to find in the literature, studies that discuss the relevance of hyperthermia induced by magnetic nanoparticles subjected to an AMF, in the treatment of gliomas. We have included preclinical testing (application of MHT in tumor models) and even clinical studies, which have been used with this technique, as therapy alone or even associated with other therapies. Although gliomas are exclusively CNS tumors, we have included animal model studies even where tumors have been implanted outside the CNS, as they originated from glioma cell lines (eg, T-9 rat glioma cells).

\section{Methods}

The search for publications was conducted from January 1990 to October 2010 based on the electronic data banks: ISI Web of Science and PubMed. The search keywords were as follows: [(Brain tumor), (glioma) or (glioblastoma)] and [(magnetic fluid hyperthermia), (magnetic hyperthermia) or (induction heating)]. In this review, three authors (LM, JBM, and TRO) independently checked the titles and abstracts of the articles obtained in the electronic search. 
Next, three other authors (LFG, LFP, and TTS) verified the quality of the methods, inclusion criteria, and data to be collected. Following this, three more authors (ACS, SMFM, and EAJr) extracted the data and tabulated the results.

The publications had to satisfy the following inclusion criteria: 1) published in English, 2) original works, 3) hyperthermia was used for the purpose of promoting glioma tumor cell death, and 4) used nanoparticles of iron oxide under the influence of an AMF as a mediator of hyperthermia.

\section{Results}

We identified 71 publications by electronic search. Considering the inclusion criteria, we selected 15 articles: 3 in vitro studies, ${ }^{28-30} 10$ animal model studies, ${ }^{23,29,31-37}$ and 2 clinical studies. ${ }^{6,27}$ Although there are different centers around the world that study magnetic hyperthermia as a cancer therapy, studies of application in glioblastoma tumors are concentrated mainly in two research centers, the Department of Biotechnology, School of Engineering, Nagoya University, Japan and the Department of Radiation Medicine, University of Chariteé Medicine, Germany.

\section{Physical parameters for efficient heating Physicochemical properties of magnetic nanoparticles}

The studies in vitro, in vivo, and in humans, in this review, used SPION corresponding to the crystalline phase of magnetite, whose physicochemical characteristics are summarized in Table 1 . In the in vitro studies, ${ }^{28-30}$ the diameter of the nucleus of the SPION ranged from 20 to $35 \mathrm{~nm}$. In vivo applications used SPION in the range of 1-35 $\mathrm{nm}$, while human studies were performed with a SPION from 12 to $15 \mathrm{~nm}$. Colloidal suspensions with various concentrations of iron, ranging from 0.2 to $1 \times 10^{7} \mathrm{mg} / \mathrm{mL}$ (Table 1 ), were employed in these studies. In all studies of this review, the hydrodynamic diameter of SPION was not notified, but the aminosilane particles produced by MagForce Nanotechnologies AG (Berlin, Germany) had a hydrodynamic diameter of $\sim 20 \mathrm{~nm} .^{38}$

For in vitro applications, the coating material of SPION was a lipid layer ( $\mathrm{N}$-( $\alpha$-trimethylammonioacetyl)-didodecylD-glutamate chloride [TMAG], dilauroylphosphatidylcholine [DLPC], dioleoylphosphatidyl-ethanolamine [DOPE], 1:2:2 cationic; DLPC, DOPE, 1:1 neutral) $)^{28,29}$ and PVP (polyvinylpyrrolidone) with poly (ethylene glycol) (200) methyl ether methacrylate (PEG200MMA), PEG1000MMA, triethylene glycol dimethacrylate (TEGDMA), and poly (ethylene glycol) (400) dymethacrylate (PEG400DMA). ${ }^{30}$ For in vivo applications, the lipid layers ${ }^{29,31-34,36}$ carboxymethylcellulose
$(\mathrm{CMC})^{37}$ and carboxydextran DDM128P6 aminosilane a $^{23}$ were used, and for human studies SPION coated with aminosilane $^{6,27}$ was used.

Most studies used magnetite coated with cationic liposomes (MCL) and SPION coated with aminosilane. For in vitro and in vivo studies that used MCL, ${ }^{28,29,31-34,36}$ the affinity of MCL to the cells, compared with the liposomes of neutral charge, was enhanced due to the electrostatic interaction on the basis of the positive charge of the MCL; a higher affinity was produced by electrostatic interaction with the phospholipid cell membrane that was negatively charged. In the in vivo studies performed with MCL for the treatment of tumors, ${ }^{32,33}$ the tumor regression was associated with the high distribution of MCL, presenting a great potential for treatment due to necrosis of the tumorigenic cells, not only by heating, but also by inducing an immune response..$^{34}$ Le et $\mathrm{al}^{35}$ have demonstrated that the MCL, besides being used for tumor hyperthermia, could also be linked to an antibody fragment, which would increase its specificity for glioma cells in vitro and in vivo. Human studies done with SPION coated with aminosilane ${ }^{6,27}$ showed that the SPION presented themselves as good specific markers in the therapy of tumors. The distribution of SPION was analyzed by autopsies on brains, which showed that the SPION installed were dispersed and distributed in aggregate forms in the region of the necrosis, and the distribution was restricted to the sites of instillation. ${ }^{27}$

\section{Alternating current (AC) magnetic field system to MHT therapy}

From Table 1 it can be observed that the oscillation frequency of the magnetic field, collected for all studies, is mainly defined as being close to $100 \mathrm{kHz}$ (ranging from 88.9 to $150 \mathrm{kHz}$ ); there is only one article that uses a frequency of $297 \mathrm{kHz} .^{30}$ The intensities of the magnetic field used to promote heating throughout the protocol are not commonly presented in the articles, but the maximum capacity of the magnetic field generators is between the values of 11.0 and $30.6 \mathrm{kA} / \mathrm{m}$. With respect to magnetic field applicator configuration, the horizontal coil and ferromagnetic core coil have been used as major setup to in vivo experiments; however, for clinical trials, the unique magnetic field applicator available has a ferrite-core configuration. In two in vitro studies, ${ }^{28,30}$ they used the configuration of the applicator in vertical coil, and in only one study ${ }^{29}$ the configuration was with a horizontal coil. In most studies, the specific loss of power or specific absorption rate are not indicated; however, studies performed by Shinkai et al, ${ }^{28}$ Le et al, ${ }^{35}$ and Rabias et $\mathrm{al}^{39}$ reported values of 140,96 , and $286 \mathrm{~W} / \mathrm{g}$, respectively. 


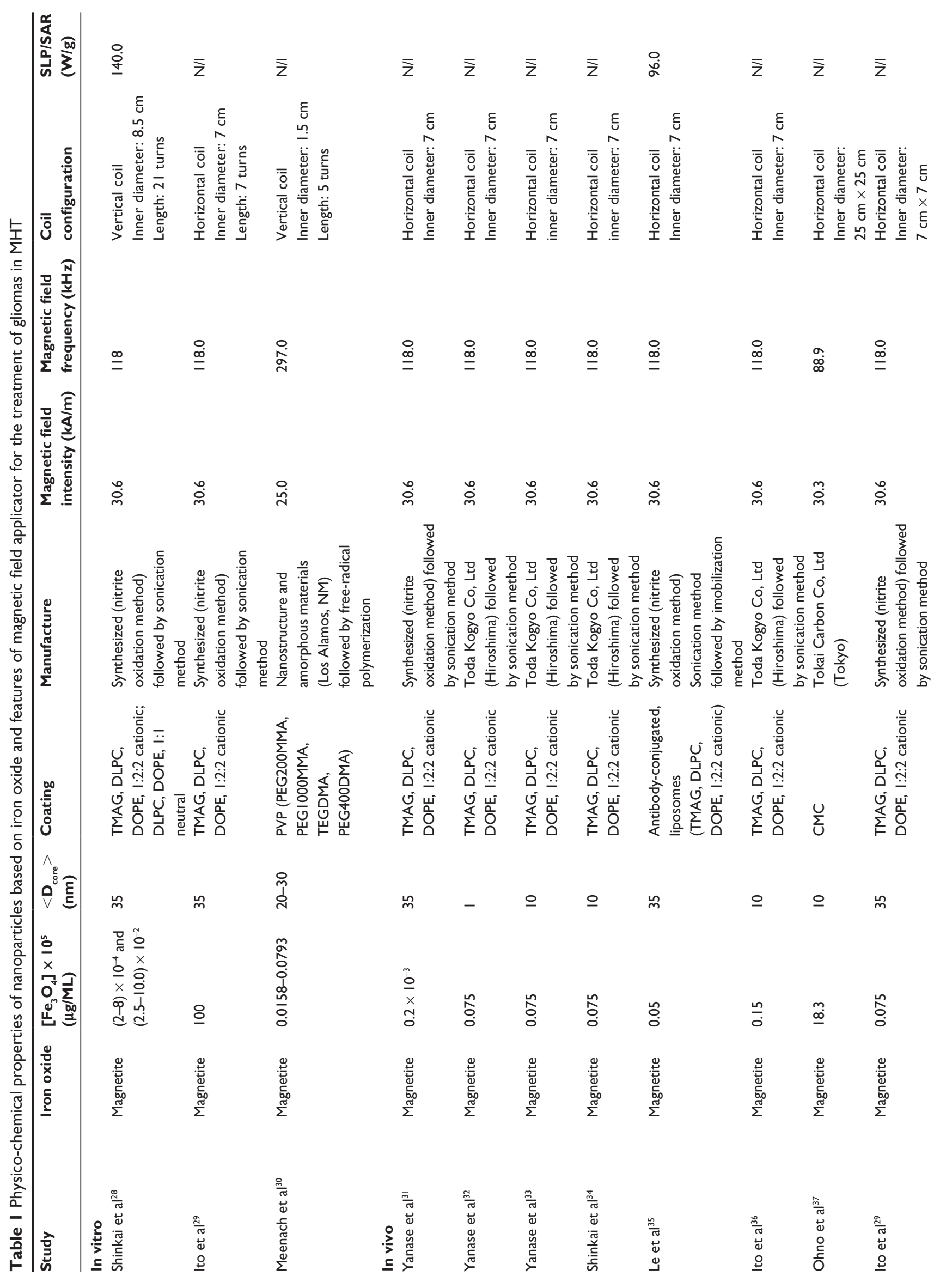




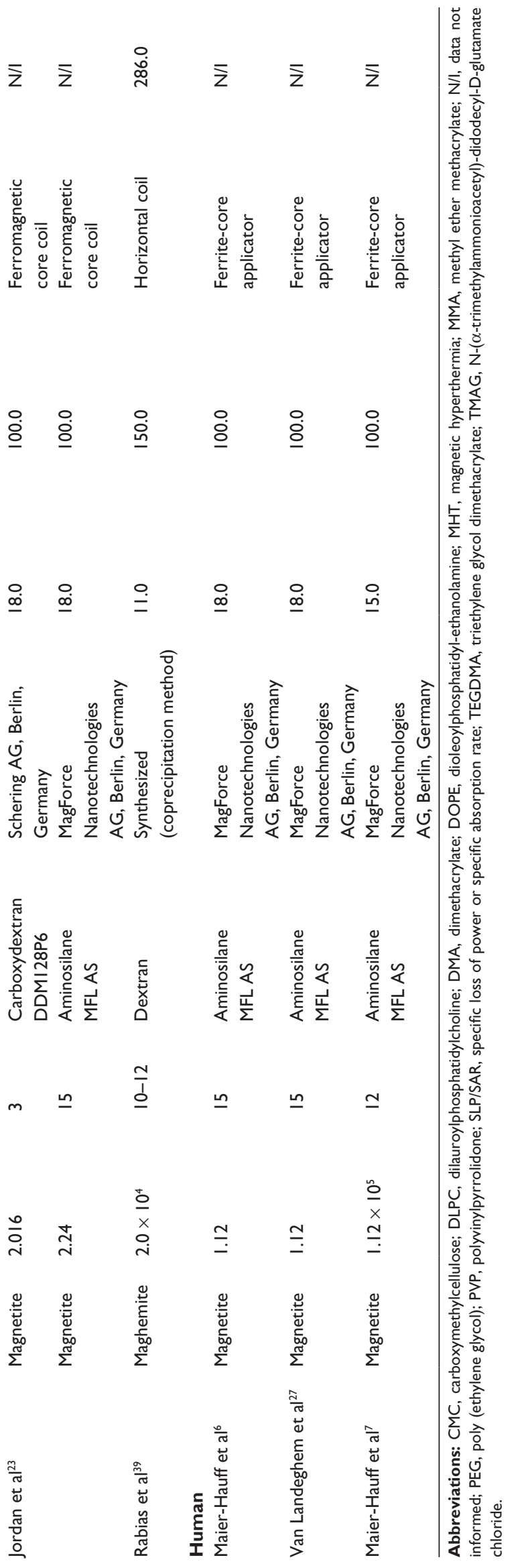

\section{Effectiveness of MHT therapy}

Of the 15 publications that we have selected for this review, 9 evaluated the MHT technique used in animal models of rats and mice; 2 performed experiments in cell culture, and 1 study used both animal and cell cultures. Three studies involved humans. The description of the results was subdivided as follows: in vitro experiments that included tests in cell culture; in vivo experiments in which animal models were used; ex-vivo and in vivo experiments in humans.

\section{In vitro experiments}

In 1996, Shinkai et $\mathrm{al}^{28}$ verified the efficiency of MCL as a generator of intracellular hyperthermia. With the application of an AMF in glioma cells (T-9), in the presence of MCL (concentration $7.2 \mathrm{mg} / \mathrm{mL}$ ), the temperature of the 'pellet' center reached $42.6^{\circ} \mathrm{C}$ in 20 minutes. Cell viability decreased when AMF was applied, reaching 0 number of cells after 40 minutes. Moreover, MCL was seen to be absorbed very well by the cells, reaching $80 \%$ of the maximum absorption in 1 hour, thereby facilitating the heating of the cells.

Posteriorly, Ito et $\mathrm{al}^{29}$ in an in vitro study, observed that hyperthermia, in addition to lysing the cells, promoted an antitumor immune response by activation of heat shock proteins (HSP70). After application of AMF, the temperature reached $42^{\circ} \mathrm{C}$ for 30 minutes by using MCL at a concentration of $100 \mu \mathrm{g} / \mathrm{mL}$. Hyperthermia promoted necrosis in three types of T-9 cell lines developed. They observed the release of HSP70 protein mainly in the type T-9/HSP70.

In another more recent study using glioblastoma cells (M059K), Meenach et $\mathrm{al}^{30}$ evaluated the ability of a hydrogel (based on polyethylene glycol) with nanoparticles, in a concentration of $7.93 \mathrm{mg} / \mathrm{mL}$, to promote hyperthermia. There was cell death by thermal ablation $\left(63^{\circ} \mathrm{C}\right)$ where hydrogel with the nanoparticles was applied, effective in the region of the plate, but there was no death in the surrounding region. Table 2 summarizes the main findings of the in vitro experiments.

\section{In vivo experiments - animal model}

Therapeutic protocol in animal models

Table 3 compares animal models and shows that the selected studies evaluate the effects of MHT therapy on tumor sizes between 3 and $18 \mathrm{~mm}$, with the highest frequency between 10 and $18 \mathrm{~mm}$, which has been included in 6 of 10 articles. One study ${ }^{37}$ did not report the size of the tumor evaluated.

The cell lines used in most studies ( 6 of 10 studies) were T-9 cells implanted into Fischer F344 rats. ${ }^{23,29,31-34,37}$ The minimum number of cells inoculated ranged from $1 \times 10^{5}$ to 


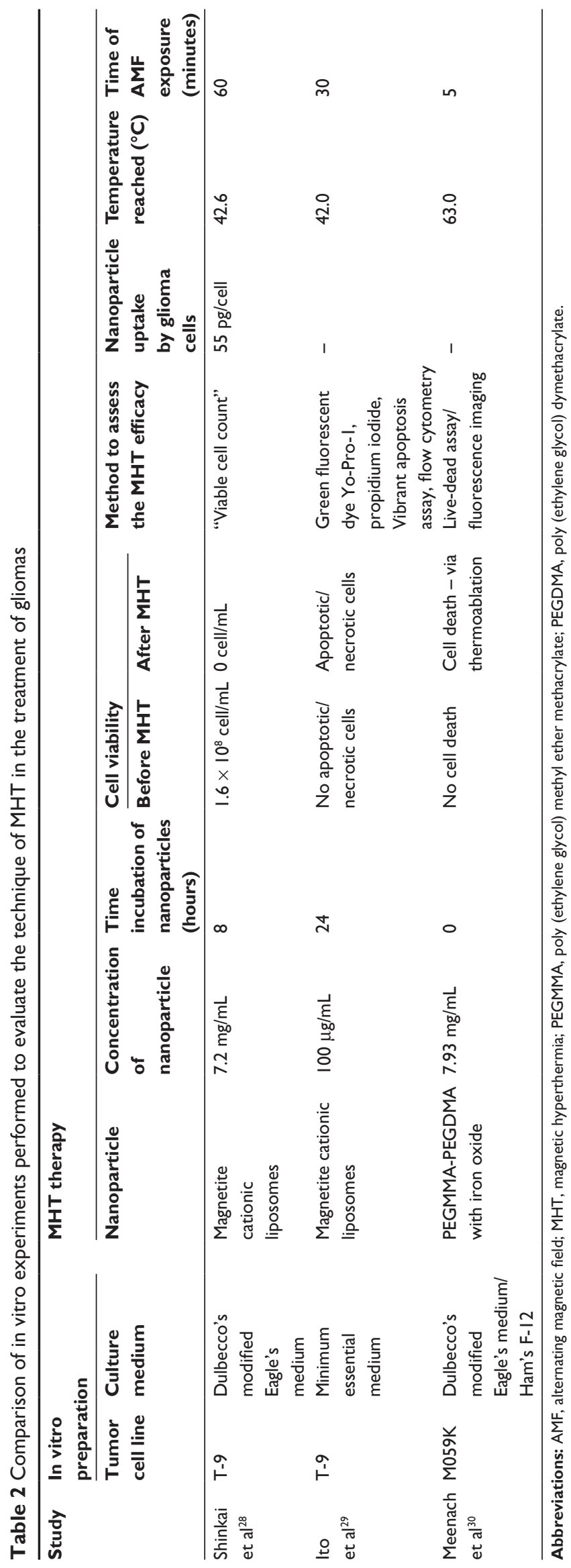

$3 \times 10^{7}$ cells. Only in 2 studies, the cells were implanted in the brain regions, ${ }^{23,37}$ and in the remaining studies, the cells were applied subcutaneously. For the interval of tumor dimension studied, the amount of iron introduced into the tumor was between $3 \mu \mathrm{g}$ and $3 \mathrm{mg}$, as per the comparison of treatment protocols presented in Table 4 and taking into consideration the nine articles that provided such information. With regard to the heating time, Table 4 shows that the authors used protocols of up to 60 minutes. However, in most studies, the duration was 30 minutes. In this sample, 7 articles favored an increase in the number of applications of AMF, with an increase in the exposure time of each application; two being the maximum number of applications observed (Table 4). The therapeutic temperature of choice was found to be between $43^{\circ} \mathrm{C}$ and $47^{\circ} \mathrm{C}$, but most often it was found to be at temperatures of $44^{\circ} \mathrm{C}^{32,34,37}$ and $45^{\circ} \mathrm{C} \cdot .^{29,31,33}$ In most studies (8 of 10 studies) MHT was tested alone; however, 2 studies $^{29,36}$ found that gene therapy added to MHT would promote a greater reduction in tumors.

\section{Effectiveness of MHT in animal models}

The effectiveness of MHT in models of gliomas was first reported by Yanase et al. ${ }^{31}$ In this study, Fisher F344 rats were used. T-9 cell cultures pre-incubated with MCL were injected subcutaneously. After 20 minutes of AMF, the temperature reached $43^{\circ} \mathrm{C}$ and went up to $45^{\circ} \mathrm{C}$. However, rectal temperature was maintained between $35^{\circ} \mathrm{C}$ and $36.5^{\circ} \mathrm{C}$. The application of AMF, thrice, for 60 minutes, at intervals of 12 hours, was able to completely inhibit tumor cell growth in rats, which were observed for up to 90 days.

In another publication, Yanase et $\mathrm{al}^{32}$ obtained similar results; however, the MCL was injected in Fisher rats with previously developed tumors. After 15 minutes of AMF, the maximum tumor temperature reached $44^{\circ} \mathrm{C}$, with little change in rectal temperature $\left(35^{\circ} \mathrm{C}\right.$ and $\left.37^{\circ} \mathrm{C}\right)$. The group that received three applications of magnetic irradiation for 30 minutes at intervals of 24 hours had a tumor reduction of $87.5 \%$. Histological analysis revealed that in the control group that received no AMF, the MCL was restricted to the area of administration. However, the groups that received AMF showed a homogeneous distribution of MCL that also coincided with the necrotic regions.

In the same year, Yanase et $\mathrm{al}^{33}$ investigated a possible antitumor immune response induced by hyperthermia in the same tumor model as described earlier in mice (T-9); however, tumor induction was performed on both sides of the animal. The heat induction was effective and reached $43^{\circ} \mathrm{C}$ in the tumor region after a 10 minute application of AMF. The group that 
Table 3 Comparison of animal models used to evaluate glioma by MHT therapy

\begin{tabular}{|c|c|c|c|c|c|c|c|c|}
\hline Study & $\begin{array}{l}\text { Tumor } \\
\text { cell line }\end{array}$ & Animal & Gender & $\begin{array}{l}\text { Age } \\
\text { (weeks) }\end{array}$ & $\begin{array}{l}\text { Injection } \\
\text { site }\end{array}$ & $\begin{array}{l}\text { Minimum } \\
\text { inoculation } \\
\text { (cells) }\end{array}$ & $\begin{array}{l}\text { Days to start } \\
\text { MHT after } \\
\text { tumor cell } \\
\text { inoculation }\end{array}$ & $\begin{array}{l}\text { Tumor } \\
\text { size }(\mathrm{mm}) / \\
\text { shape }\end{array}$ \\
\hline $\begin{array}{l}\text { Yanase } \\
\text { et al }{ }^{31}\end{array}$ & T-9 & $\begin{array}{l}\text { Fisher } \\
\text { rat F-344 }\end{array}$ & Female & $7-8$ & $\begin{array}{l}\text { Subcutaneous } \\
\text { (left femoral } \\
\text { region) }\end{array}$ & $1 \times 10^{6}$ & - & 3/ellipsoidal \\
\hline $\begin{array}{l}\text { Yanase } \\
\text { et al }{ }^{32}\end{array}$ & T-9 & $\begin{array}{l}\text { Fisher } \\
\text { rat F-344 }\end{array}$ & Female & $6-7$ & $\begin{array}{l}\text { Subcutaneous } \\
\text { (left femoral } \\
\text { region) }\end{array}$ & $1 \times 10^{7}$ & 11 & $\begin{array}{l}\text { |3-|8/ } \\
\text { ellipsoidal }\end{array}$ \\
\hline $\begin{array}{l}\text { Yanase } \\
\text { et } \mathrm{al}^{33}\end{array}$ & T-9 & $\begin{array}{l}\text { Fisher } \\
\text { rat F-344 }\end{array}$ & Female & $6-7$ & $\begin{array}{l}\text { Subcutaneous } \\
\text { (left and right } \\
\text { femoral region) }\end{array}$ & $1 \times 10^{7}$ & 11 & $\begin{array}{l}\text { |3-|8/ } \\
\text { ellipsoidal }\end{array}$ \\
\hline $\begin{array}{l}\text { Shinkai } \\
\text { et } \mathrm{al}^{34}\end{array}$ & T-9 & $\begin{array}{l}\text { Fisher } \\
\text { rat F-344 }\end{array}$ & Female & $6-7$ & $\begin{array}{l}\text { Subcutaneous } \\
\text { (left femoral } \\
\text { region) }\end{array}$ & $1 \times 10^{7}$ & 11 & $\begin{array}{l}\text { |3-|8/ } \\
\text { ellipsoidal }\end{array}$ \\
\hline Ito et $\mathrm{al}^{36}$ & U-25I-SP & $\begin{array}{l}\text { Athymic } \\
\text { nude mice }\end{array}$ & Female & 4 & Right flank & $3 \times 10^{7}$ & - & $8 /-$ \\
\hline Le et $\mathrm{al}^{35}$ & U-25I-SP & $\begin{array}{l}\mathrm{KSN} \text {-nu/nu } \\
\text { nude mice }\end{array}$ & Female & 4 & $\begin{array}{l}\text { Subcutaneous } \\
\text { (femoral region) }\end{array}$ & - & 21 & $\begin{array}{l}\text { I0/ } \\
\text { ellipsoidal }\end{array}$ \\
\hline $\begin{array}{l}\text { Ohno } \\
\text { et } \mathrm{al}^{37}\end{array}$ & T-9 & $\begin{array}{l}\text { Fisher } \\
\text { rat F-344 }\end{array}$ & Female & 4 & $\begin{array}{l}\text { Right cerebral } \\
\text { hemisphere }\end{array}$ & $5 \times 10^{6}$ & 8 & - \\
\hline Ito et $\mathrm{al}^{29}$ & T-9 & $\begin{array}{l}\text { Fisher } \\
\text { rat F-344 }\end{array}$ & Female & 6 & $\begin{array}{l}\text { Subcutaneous } \\
\text { space }\end{array}$ & $1 \times 10^{7}$ & - & $10 /-$ \\
\hline $\begin{array}{l}\text { Jordan } \\
\text { et } \mathrm{al}^{23}\end{array}$ & RG-2 & $\begin{array}{l}\text { Fisher } \\
\text { rat F-344 }\end{array}$ & Male & - & $\begin{array}{l}\text { Thalamus } \\
\text { region }\end{array}$ & $1 \times 10^{5}$ & 4 & 3-4/round \\
\hline $\begin{array}{l}\text { Rabias } \\
\text { et a }{ }^{39}\end{array}$ & $\mathrm{C} 6$ & Wistar rat & Male & - & $\begin{array}{l}\text { Subcutaneous } \\
\text { (anterior } \\
\text { bregma region) }\end{array}$ & $8 \times 10^{6}$ & 28 & $5-10 /-$ \\
\hline
\end{tabular}

Abbreviation: MHT, magnetic hyperthermia.

received three sessions of 30 minutes of magnetic irradiation, with intervals of 24 hours, had a complete regression of the tumor on the left side. Although the right side did not receive an application of MCL, it also had total regression of the tumor. Histological analysis revealed the presence of immunocytes (CD3, CD4, CD8, and natural killer [NK] cells) in the group exposed to hyperthermia in the tumor tissues on both sides (left and right). After magnetic irradiation, the cured rats were injected again with T-9 cells and also with cell lines of malignant fibrous histiocytoma (MFH). The authors observed the development of MFH cells only, showing a specific immune response of the tissue to T-9 cells.

The same antitumor immune response triggered by hyperthermia, proposed by Yanase, ${ }^{32}$ was confirmed by Shinkai et al. ${ }^{34}$ Soon after tumor growth (T-9 cells) in Fisher rats, after a 15-minute application of AMF, it was observed that the maximum temperature in the tumor reached $44^{\circ} \mathrm{C}$. The maximum duration of application of AMF was 30 minutes, and in this time interval, animals in the group receiving magnetic irradiation had a complete regression of the tumor after repeated sessions. After regression, no recurrence was observed for a 3-month period. Injected MCL of $80 \%$ to $90 \%$ accumulated in the tumor tissue. It was suggested that regression and no recurrence of tumor was on account of an immune response (activation of CD4, CD8, and NK cells) activated by hyperthermia.

In 2001, Ito et $\mathrm{al}^{36}$ suggested that hyperthermia combined with gene therapy could be an effective therapy for the treatment of tumors. For the development of the tumors, human glioma cells (U251-SP) were implanted in the flanks of mice. The application of AMF in the tumor, in the presence of MCL, was able to produce heating to $46^{\circ} \mathrm{C}$ after 3 minutes. The concomitant injection in the tumor of pGadFNT, a promoter of the tumor necrosis factor (TNF) that was activated by hyperthermia and MCL, promoted an increase of gene expression, TNF- $\alpha$, after the application of AMF. Application of pGadFNT and MCL and subsequent application of AMF dramatically reduced the tumor, and it was the largest decrease compared with groups in which these compounds were administered alone.

Also in 2001, Le et a ${ }^{35}$ demonstrated that the effectiveness of MCL in the destruction of tumors could be increased when 


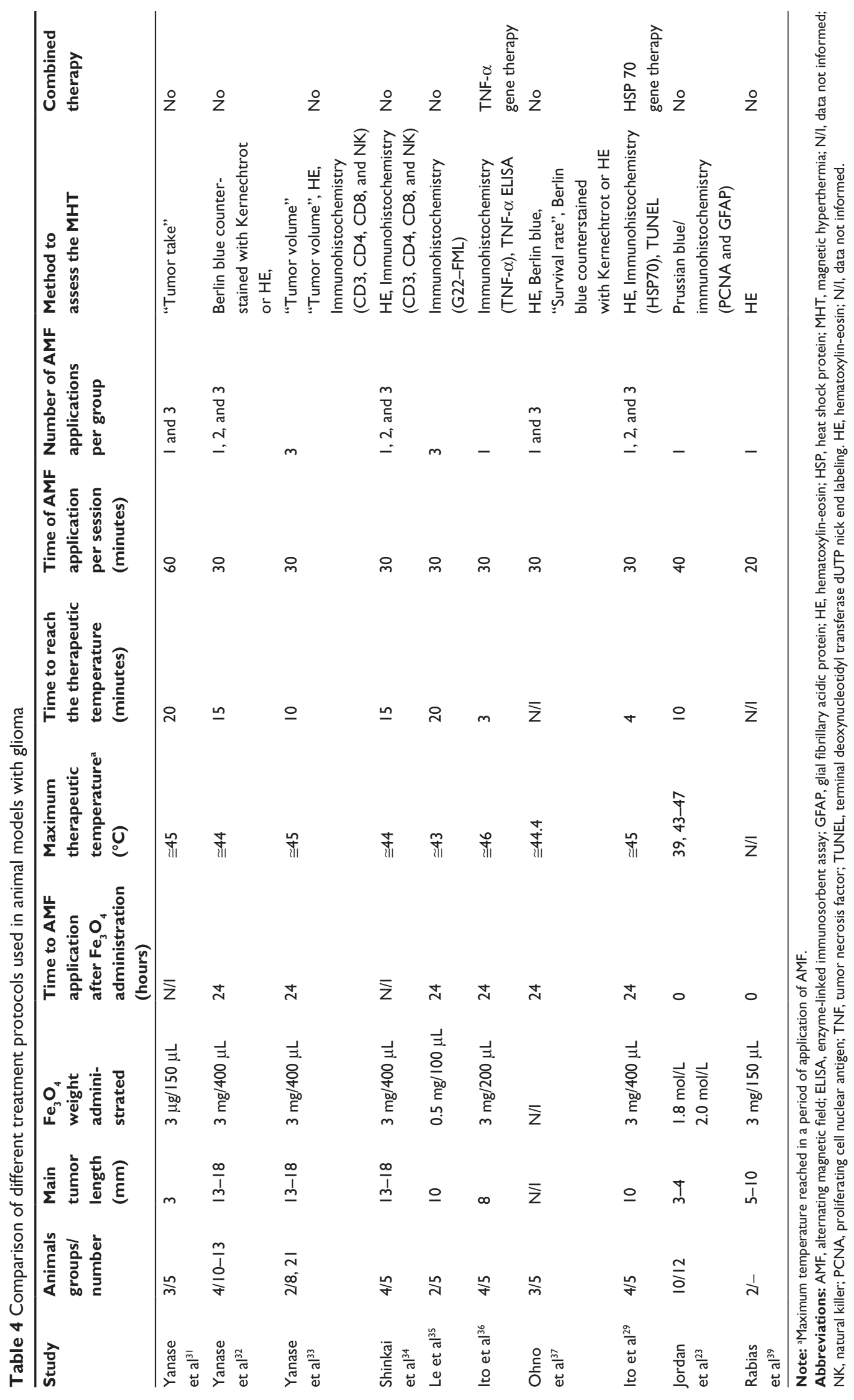


it was coupled with a fragment of a specific antibody for tumors (Fab fragment). Thus, tumors were developed in mice with human glioma cells (U251-SP). It was found that the MCL conjugated to the antibody Fab was captured by tumor cells seven times more than MCL without a specific antibody, and after application of AMF, there was a rapid increase in tumor temperature reaching $40^{\circ} \mathrm{C}$ in 5 minutes and $43^{\circ} \mathrm{C}$ after 30 minutes. Moreover, tumor growth was inhibited for up to 2 weeks.

In 2002, Ohno et $\mathrm{al}^{37}$ tested the efficacy of a new SPION, CMC 'stick type', based on a magnetite, in the generation of heat. This SPION was evaluated in tumors developed in Fisher rat brains that were inoculated with T-9 cells. The nanoparticles were effectively heating the tumor tissue to $44.4^{\circ} \mathrm{C}$, after AMF application, besides being widely distributed after three applications. It was found that the nanoparticles did not invade normal brain tissues surrounding the tumor. Total remission of the tumor was observed in only one animal in the group, which underwent three sessions of MHT. Moreover, this group verified higher survival when compared with other groups. Thus, the data showed a good performance by the nanoparticles in the induction of hyperthermia.

In the studies of Ito et al, hyperthermia was still identified as an inducer of antitumor immune factors. ${ }^{29}$ In this study, it was hypothesized that hyperthermia activated HSPs, which in turn triggered an antitumor immune response. Tumors in Fisher rats developed from the inoculation of T- 9 cells into the subcutaneous space. The application of AMF in the tumor, in the presence of $\mathrm{MCL}$, was able to produce heating up to $42^{\circ} \mathrm{C}$ after 4 minutes, reaching $45^{\circ} \mathrm{C}$. Along with the heating there was an increase in HSP70 protein expression. It was observed that the HSP70 protein was able to trigger an antitumor immune response. Moreover, it was found that on account of hyperthermia the dead cells released HSP70 protein.

Recently, Jordan et $\mathrm{al}^{23}$ observed the efficiency of hyperthermia promoted by SPION with two different types of coatings (carboxidextran and aminosilane) in an animal model of brain tumor (RG-2). In relation to the controls, after MHT, the tumors did not differ in dimension or histopathology. There was a decrease in the level of cell proliferation in the group that used nanoparticles coated with aminosilane. In the same group there was an increase in the average survival of animals. The gain in survival was correlated with increased intratumoral temperature, observed during the treatment. Nanoparticles coated with aminosilane remained stable within the tumor when compared with those coated with carboxidextran, and were well distributed in the tumor tissue after histological analysis. It was concluded that thermotherapy using SPION coated with aminosilane was effective in causing an extension of survival in animals submitted to the tumor model.

Finally, Rabias et $\mathrm{al}^{39}$ demonstrated in a study of synthesis and characterization, the efficiency of a maghemite ferrofluid coated with dextran with high surface charge (denominated S3). The results showed that even with the injection of small quantities, there was a rapid heating and good distribution in tumor. An amount of $150 \mathrm{uL}$ of ferrofluid was injected into extracranial tumors developed from the C6 cell line in Wistar rats.

During the application of AMF of low intensity $(11 \mathrm{kA} / \mathrm{ma}$ $150 \mathrm{kHz}$ for 20 minutes), performed by monitoring the temperature with infrared image, they observed that the heating was restricted to the tumor area. After treatment, animals were submitted to histological analysis, and there was extensive damage or even the dissolution of the tumor tissue. This damage was restricted to the tumor area. In control groups where the ferrofluid was injected without application of a magnetic field or even in the group that there was no injection, but the animals were submitted to AMF, there was no detected tumor damage. Thus, they concluded that the ferrofluid tested, due to its high surface charge, prevented the formation of clusters, with a good dispersion in tumor tissue during heating, showing its excellent applicability in living organisms.

The main findings observed in the studies using animal models for evaluation of MHT to treat gliomas are summarized in Table 3.

\section{In vivo and ex-vivo experiments in humans}

Clinical studies were started by Maier-Hauff et al, ${ }^{6}$ wherein the efficacy and tolerability of hyperthermia induced by SPION-coated aminosilane combined with radiotherapy was evaluated in 14 patients for the treatment of recurrent glioblastoma multiforme. The eligibility criteria for the study were: age greater than or equal to 18 years, life expectancy greater than 3 months, tumor diameter less than $5 \mathrm{~cm}$, no multilocular growth, and no metal material near the tumor focus. Each patient received an average of six sessions of thermotherapy. These sessions were preceded with instillation of approximately $0.2 \mathrm{~mL}$ of magnetic fluid per $\mathrm{mL}$ tumor volume. The average intratumoral temperature reached during the sessions was $44.6^{\circ} \mathrm{C}$.

After each thermotherapy session, the patients underwent a simple fraction (2 Gy) of radiotherapy series of $30 \mathrm{~Gy}$, on average. All the patients were tolerant of the instillation of SPION, not showing any complications or adverse effects. 
The implementation of AMF brought few side effects, except in some patients who complained of a mild heating sensation in the head. Aspects for survival and local tumor growth were analyzed. Nine patients had their deaths related to tumor progression; however, four deaths were not related to tumor growth or thermotherapy, but were a result of prescription medication. It was concluded that MHT could be satisfactorily used in treating brain tumors because they could be safely applied in patients with glioblastoma, with minimal or no local symptoms.

In 2009, Van Landeghem et $\mathrm{al}^{27}$ presented the first postmortem neuropathological study of three patients with glioblastoma undergoing MHT (Table 5). In this study, the eligibility criteria were: greater than or equal to 18 years, life expectancy greater than 3 months, tumor diameter less than $5 \mathrm{~cm}$, no multilocular growth, and no metal material near the tumor focus. After recurrence of the tumor, MHT was applied as a second line of treatment and was always associated with other therapies (see Table 5). The quantity of magnetic liquid instilled into the tumor varied from 4.2 to $4.5 \mathrm{~mL}$. With the application of AMF, the temperature achieved among the patients ranged between $49.5^{\circ} \mathrm{C}$ and $65.6^{\circ} \mathrm{C}$.

After application of the MHT, survival ranged from 2.1 to 7.9 months (for details see Table 5). The anatomopathological results and other findings listed in Table 5 describe the presence of many nanoparticles in the tumor region, macrophages in the main extension, and a subsequent necrotic area inherent in the tumor. A histological analysis showed that the nanoparticles injected were dispersed or in the form of clusters, and that the necrotic regions were confined to the local instillation of nanoparticles, indicating the need for instillation in multiple locations. Immunohistochemical data revealed that the internalization of the nanoparticles was mainly driven by macrophages and minimally by tumor cells. It was suggested that the internalization by macrophages would be promoted by applying MHT and yet it promoted necrosis with subsequent infiltration and activation of phagocytes.

Later, Maier-Hauff et $\mathrm{al}^{7}$ presented a study of 66 patients using the MHT associated with radiotherapy. In this study, they investigated whether MHT was able to increase survival of patients with recurrent glioblastoma multiforme. The criteria for eligibility were: histological diagnosis of supratentorial glioblastoma; evidence of recurrence or progression with up to three additional foci; tumor with a maximum of $7 \mathrm{~cm}$; absence of tumor infiltration in the ventricle, brain stem, corpus callosum, or the contralateral side; aged between 18 and 75 years; score $\geq 69$ in the Karnofsky test; and life expectancy of up to 3 months. Seven of 66 patients did not attend the inclusion criteria, which resulted in 59 patients

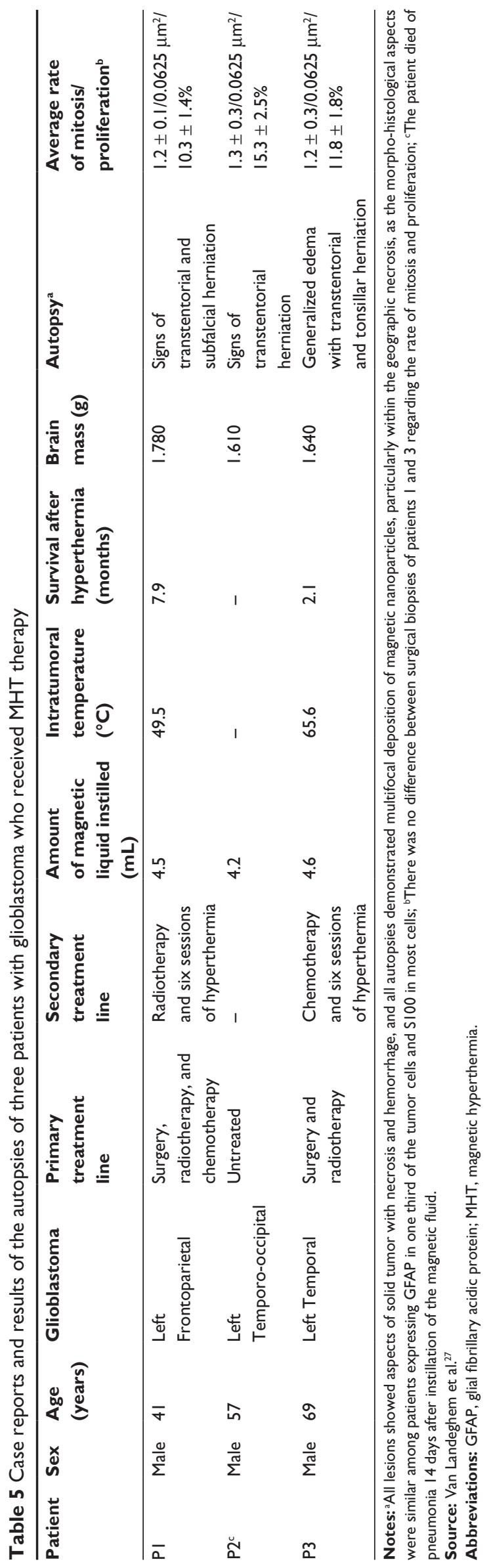


being included in the survival statistical analysis. The average of ferrofluid injected was $4.5 \mathrm{~mL}$, corresponding to an average of $0.28 \mathrm{~mL}$ of ferrofluid per $\mathrm{cm}^{3}$ of tumor volume. The AMF $(100 \mathrm{kHz})$ applied ranged from 2 to $15 \mathrm{kA} / \mathrm{m}$. Radiotherapy was applied before or after thermotherapy, with an average dose of $30 \mathrm{~Gy}$, using fractions of $5 \times 2$ Gy weekly.

In general, two aspects were studied: patient survival after the diagnosis of first recurrence of the tumor (OS-2) and survival after the diagnosis of primary tumor (OS-1). In the OS-2 group, the average survival of 13.4 months was higher compared with 6.2 months in conventional treatments realized by Stupp et al. ${ }^{40}$ The OS- 1 group average was 23.2 months in contrast with the study by Stupp, where the average was 14.6 months. In this study, the increase in survival of patients could be correlated to thermotherapy in association with radiotherapy. In addition, thermotherapy showed few side effects and no serious complication, being a good treatment option when compared with conventional therapies.

\section{Discussion}

The studies selected for this review sought to evaluate the use of the technique of MHT to treat gliomas with assays in cell culture, animal models, and clinical trials. Some of these studies showed possible mechanisms triggered by hyperthermia leading to death of the tumor cells, in addition to associating hyperthermia with other therapeutic modalities.

The studies that were aimed at the use of MHT in glioma cells (T-9) began with Shinkai, ${ }^{28}$ through the development of nanoparticles coated with cationic liposomes (MCL), as they were efficient in generating heat, besides having a high affinity to the cell surface, as they are positively charged. The efficiency of MCL was confirmed by Yanase ${ }^{31}$ with glioma T-9 cells, preincubated with MCL which were destroyed after subcutaneous implantation in Fisher rats and subsequent application of AMF. Yanase et $\mathrm{al}^{32}$ also observed that MCL had good distribution after application of AMF, and the best therapeutic strategy in Fisher rats that had developed tumors was the application of three sessions of magnetic radiation. With these studies, it was concluded that MCL could be a nanoparticle functionalized with a good performance for application in MHT.

After confirming the efficiency of MCL, these authors sought to investigate the mechanisms of destruction of glioma tumor cells that could be triggered by MHT. Yanase et $\mathrm{al}^{33}$ proposed that MHT would be responsible for an antitumor immune response. In this study, they found that hyperthermia induced and promoted an increase of immune cells CD3, CD4, and CD8, and NK cells, in the tumor tissue of Fisher rats.
In the following year, Shinkai et $\mathrm{al}^{34}$ obtained similar results to those obtained from the studies of Yanase in Fisher rats that received three sessions of hyperthermia, and they noted a significant antitumor immune response against repeated inductions of heat. Following this line of study, in 2003, Ito et $\mathrm{al}^{29}$ demonstrated that the immune response observed in tumors undergoing MHT would be primarily activated by HSPs that had increased from the elevation of temperature, both in in vitro and in vivo experiments. A significant increase in HSP70 was observed in this study.

From the year 2000, there was an intention of associating hyperthermia with other therapies for the treatment of gliomas. Ito et $\mathrm{al}^{36}$ found that the application of a promoter of TNF (pGadFNT) associated with the MCL in the tumor and the subsequent application of AMF would lead to overexpression of TNF- $\alpha$, significantly reducing the tumor tissue. Similarly, Le et $\mathrm{al}^{35}$ found an increased affinity of MCL to tumorigenic cells with the association of an antibody fragment (Fab), leading to a reduction in tumor growth. These data suggested that hyperthermia associated with other therapies could potentiate its effect.

In 2002, studies that sought new nanocomposites with different coatings, which were able to destroy glioma cells by generating heat, were initiated. In this sense, Ohno et $\mathrm{al}^{37}$ evaluated the efficacy of stick-type CMC. It was noted, after three sessions of AMF, that there was a good distribution of these nanoparticles in the tumor tissue, with no detection in the tissues surrounding the tumor. The efficient heating through these nanoparticles led to remission of the tumors. By then, Jordan et $\mathrm{al}^{23}$ had tested two new coats: carboxidextran and aminosilane. Aminosilane was more effective compared with carboxidextran, showing a decrease in cell proliferation in the region of the tumor and an increase in the survival of animals that used this nanoparticle. Yet, in the evaluation of new nanocomposites, Meenach et $\mathrm{al}^{30}$ verified in in vitro tests, the ability of nanoparticles immersed in hydrogel (PEG) to promote hyperthermia. The application of hydrogel lysed glioblastoma cells into the culture did not affect the cells that were around the gel, showing their effectiveness in reaching only cells bathed by the gel.

Recently, Rabias et $\mathrm{al}^{39}$ characterized a new nanoparticle with a high surface charge (maghemite coated with dextran) with excellent heating in both in vitro and in vivo tests. In this study, the model of glioblastoma was performed in Wistar rats (model C6). The heating was achieved satisfactorily with the instillation of small volumes of ferrofluid, and presented a good distribution in tumor. The nanoparticle was able, in some cases, to promote complete dissolution of the tumor tissue. Its efficiency was attributed to higher surface charge and the need for small volumes to get a good warming-up. 
The development of new nanocomposites made the hyperthermia process effective in achieving the desired temperature in a localized manner, which brought great benefits to patients who used this treatment.

Clinical studies of MHT began with Jordan et $\mathrm{al}^{41}$ who presented a new system of application of the magnetic field to generate hyperthermia, using magnetic fluids, for future applications in the treatment of glioblastomas and prostate carcinoma. However, in 2007, Maier-Hauff et $\mathrm{al}^{6}$ presented a clinical study of 14 patients where MHT was applied (combined with radiotherapy) for the treatment of glioblastomas. A good tolerability to the technique was observed by the patients, without any major side effects. Four patients in this study died, although their deaths were not related to tumor progression or thermotherapy. This could be an indication that the technique of MHT would stop the development of the tumor, thus promising the use of thermotherapy in tumor control, but it is still necessary to have many more studies. In 2009, Van Landeghem et $\mathrm{al}^{27}$ performed a postmortem study in patients with glioblastoma undergoing MHT. The anatomopathological examination verified the presence of many nanoparticles that were dispersed or in an aggregated form, in the tumor tissues. The necrotic regions were limited to areas of instillation of the nanoparticles, which showed that application to more areas was necessary to reach all tumor tissues. It was also found that internalization of the nanoparticles was mainly driven by macrophages and not by tumor cells.

In 2010, following the clinical studies, Maier-Hauff et $\mathrm{al}^{7}$ performed a study of 69 patients with recurrent glioblastoma who underwent radiotherapy in combination hyperthermia induced by magnetic nanoparticles. The results of this paper displayed differently to their initial studies, an increase in patient survival when compared with conventional therapies. ${ }^{40}$

Another advantage was the low doses of radiation applied, suggesting that thermotherapy had a major role in increasing survival to these patients. Moreover, it was proposed that this new therapy can be applied in other tumor tissues of the body, since they have similar sensitivity to warming.

\section{Conclusion}

In this review we have discussed the application of magnetic hyperthermia for the treatment of gliomas. MHT had its efficacy demonstrated through experiments in vitro where the application of MHT to tumor cell culture promoted cell death by necrosis and/or apoptosis, or even via thermal ablation. This effectiveness was confirmed in the experimental models of rodents where an increase in survival and, in some cases, a decrease or total regression of tumor mass was observed. In addition, in the first clinical trials, MHT was seen to be promising when combined with other conventional therapies, as a complementary therapy.

Based on these data, we can conclude that MHT has shown to be effective in many cases; however, an improvement of nanocomposites as well as the upgrading of equipment for induction of AMF, could contribute to the establishment of technique in the treatment of gliomas.

\section{Acknowledgment}

This work was supported by Instituto Israelita de Ensino e Pesquisa Albert Einstein (IIEP), CNPq, FINEP/CAPES.

\section{Disclosure}

The authors report no conflicts of interest in this work.

\section{References}

1. CBTRUS: Central Brain Tumor Registry of the United States. Primary Brain Tumors in the United States, Statistical Report, 2004-2006. Available from: http://www.cbtrus.org/2010-NPCR-SEER/CBTRUSWEBREPORT-Final-3-2-10.pdf. Accessed August 2, 2010.

2. ABTA: American Brain Tumor Association. Gliomas. Available from: http://www.abta.org/index.cfm?contentid=230\&Glioma-Glioblastomaoligodendroglioma. Accessed November 30, 2009.

3. Parney IF, Hao C, Petruk KC. Glioma immunology and immunotherapy. Neurosurgery. 2000;46(4):778-791.

4. Brandes AA, Tosoni A, Franceschi E, Reni M, Gatta G, Vecht C. Glioblastoma in adults. Crit Rev Oncol Hematol. 2008;67:139-152.

5. Wen PY, Kesari S. Malignant gliomas in adults. $N$ Engl J Med. 2008;359:492-507.

6. Maier-Hauff K, Rothe R, Scholz R, et al. Intracranial thermotherapy using magnetic nanoparticles combined with external beam radiotherapy: results of a feasibility study on patients with glioblastoma multiforme. J Neurooncol. 2007;81:53-60.

7. Maier-Hauff K, Uldrich F, Nestler D, et al. Efficacy and safety of intratumoral thermotherapy using magnetic iron-oxide nanoparticles combined with external beam radiotherapy on patients with recurrent glioblastoma multiforme. J Neurooncol. September 16, 2010. [Epub before print].

8. Cavaliere R, Ciocatto EC, Giovanella BC, et al. Selective heat sensitivity of cancer cells - biochemical and clinical studies. Cancer. 1967;20(9): $1351-1381$.

9. Sellins KS, Cohen JJ. Hyperthermia induces apoptosis in thymocytes. Rad Res. 1991;126(1):88-95.

10. Christophi C, Winkworth A, Muralihdaran V, Evans P. The treatment of malignancy by hyperthermia. Surgical Oncology-Oxford. 1998; 7(1-2):83-90.

11. Coss RA, Linnemans WA. The effects of hyperthermia on the cytoskeleton: a review. Int J Hyperthermia. 1996;12:173-196.

12. Lepock JR. Cellular effects of hyperthermia: relevance to the minimum dose for thermal damage. Int J Hyperthermia. 2003;19: 252-266.

13. Wong RSL, Kapp LN, Krishnaswamy G, Dewey WC. Critical steps for induction of chromosomal aberrations in $\mathrm{CHO}$ cells heated in $\mathrm{S}$ phase. Radiat Res. 2003;133:52-59.

14. Sneed PK, Stauffer PR, McDermott MW, et al. Survival benefit of hyperthermia in a prospective randomized trial of brachytherapy boost +/-hyperthermia for glioblastoma multiforme. Int J Radiat Oncol Biol Phys. 1998;40:287-295. 
15. Stahl H, Wust P, Maier-Hauff K, Seebass M, et al. The use of an early postoperative interstitial-hyperthermia combination therapy in malignant gliomas. Strahlenther Onkol. 1995;171:510-524.

16. Mitsumori M, Hiraoka M, Okuno Y, et al. A phase I and II clinical trial of a newly developed ultrasound hyperthermia system with an improved planar transducer. Int J Radiat Oncol Biol Phys. 1996;36:1169-1175.

17. Guthkelch AN, Carter LP, Cassady JR, et al. Treatment of malignant brain tumors with focused ultrasound hyperthermia and radiation: results of a phase I trial. J Neurooncol. 1991;10(3):271-284.

18. Guilhon E, Voisin P, de Zwart JA, et al. Spatial and temporal control of transgene expression in vivo using a heat-sensitive promoter and MRI-guided focused ultrasound. J Gene Med. 2003;5(4): 333-342.

19. Wismeth C, Dudel C, Pascher C, et al. Transcranial electro-hyperthermia combined with alkylating chemotherapy in patients with relapsed high-grade gliomas: phase I clinical results. J Neurooncol. 2010;98(3): 395-405.

20. Gilchrist RK, Medal R, Shorey WD, Hanselman RC, Parrott JC, Taylor CB. Selective inductive heating of lymph nodes. Ann Surg. 1957;146:596-606.

21. Brusentsov NA, Nikitin LV, Brusentsova TN, et al. Magnetic fluid hyperthermia of the mouse experimental tumor. J Magn Magn Mater. 2002;252(1-3):378-380.

22. Johannsen M, Gneveckow U, Eckelt L, et al. Clinical hyperthermia of prostate cancer using magnetic nanoparticles: presentation of a new interstitial technique. Int J Hyperthermia. 2005;21(7):637-647.

23. Jordan A, Scholz R, Maier-Hauff K, et al. The effect of thermotherapy using magnetic nanoparticles on rat malignant glioma. J Neurooncol. 2006;78:7-14.

24. Thiesen B, Jordan A. Clinical applications of magnetic nanoparticles for hyperthermia. Int J Hyperthermia. 2008;24(6):467-474.

25. Mornet S, Vasseur S, Grasset F, et al. Magnetic nanoparticle design for medical applications. Progress Solid State Chem. 2006;34: 237-247.

26. Hergt R, Dutz S. Magnetic particle hyperthermia - biophysical limitations of a visionary tumour therapy. J Magn Magn Mater. 2007; 311:187-192.

27. Van Landeghem FKH, Maier-Hauff K, Jordan A, et al. Post-mortem studies in glioblastoma patients treated with thermotherapy using magnetic nanoparticles. Biomaterials. 2009;30:52-57.

28. Shinkai M, Yanase M, Honda H, Wakabayashi T, Yoshida J, Kobayashi T. Intracellular hyperthermia for cancer using magnetite cationic liposomes in vitro study. Jpn J Cancer Res. 1996;87:1179-1183.
29. Ito A, Shinkai M, Honda $H$, et al. Heat shock protein 70 expression induces antitumor immunity during intracellular hyperthermia using magnetite nanoparticles. Cancer Immunol Immunother. 2003;52: 80-88.

30. Meenach SA, Hilt JZ, Anderson KW. Poly(ethylene glycol)-based magnetic hydrogel nanocomposites for hyperthermia cancer therapy. Acta Biomater. 2010;6(3):1039-1046.

31. Yanase M, Shinkai M, Honda H, Wakabayashi T, Yoshida J, Kobayashi T. Intracellular hyperthermia for cancer using magnetite cationic liposomes: ex vivo study. Jpn J Cancer Res. 1997;88:630-632.

32. Yanase M, Shinkai M, Honda H, Wakabayashi T, Yoshida J, Kobayashi T. Intracellular hyperthermia for cancer using magnetite cationic liposomes: an in vivo study. Jpn J Cancer Res. 1998;88:463-470.

33. Yanase M, Shinkai M, Honda H, Wakabayashi T, Yoshida J, Kobayashi T. Antitumor immunity induction by intracellular hyperthermia using magnetite. Jpn J Cancer Res. 1998;89:775-782.

34. Shinkai M, Yanase M, Mitsugu Y, et al. Intracellular hyperthermia for cancer using magnetite cationic liposomes. J Magn Magn Mater. 1999; 194:176-184.

35. Le B, Shinkai M, Kitade T, et al. Preparation of tumor-specific magnetoliposomes and their application for hyperthermia. J Chem Eng Japan. 2001;34(1):66-72.

36. Ito A, Shinkai M, Honda H, Kobayashi T. Heat-inducible TNF- $\alpha$ gene therapy combined with hyperthermia using magnetic nanoparticles as a novel tumor-targeted therapy. Cancer Gene Ther. 2001;8(9): 649-654.

37. Ohno T, Wakabayashi T, Takemura A, et al. Effective solitary hyperthermia treatment of malignant glioma using stick type CMC-magnetite: in vivo study. J Neurooncol. 2002;56:233-239.

38. MagForce Nanotechnologies AG. Available from: http://www.magforce. de/english/products/nano-cancer-therapy.html. Accessed November 15, 2009.

39. Rabias I, Tsitrouli D, Karakosta E, et al. Rapid magnetic heating treatment by highly charged maghemite nanoparticles On Wistar rats exocranial glioma tumors at microliter volume. Biomicrofluidics. 2010:4(2). pii: 024111.

40. Stupp R, Hegi ME, Mason WP, et al. Effects of radiotherapy with concomitant and adjuvant temozolomide versus radiotherapy alone on survival in glioblastoma in a randomised phase III study: 5-year analysis of the EORTC-NCIC trial. Lancet Oncol. 2009;10:459-466.

41. Jordan A, Scholz R, Maier-Hauff K, et al. Presentation of a new magnetic field therapy system for the treatment of human solid tumors with magnetic fluid hyperthermia. J Magn Magn Mater. 2001;225: $118-126$.
International Journal of Nanomedicine

\section{Publish your work in this journal}

The International Journal of Nanomedicine is an international, peerreviewed journal focusing on the application of nanotechnology in diagnostics, therapeutics, and drug delivery systems throughout the biomedical field. This journal is indexed on PubMed Central,

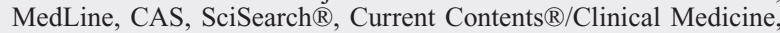

\section{Dovepress}

Journal Citation Reports/Science Edition, EMBase, Scopus and the Elsevier Bibliographic databases. The manuscript management system is completely online and includes a very quick and fair peer-review system, which is all easy to use. Visit http://www.dovepress.com/ testimonials.php to read real quotes from published authors. 